\title{
Yield and quality of grapes cultivated under plastic coverings with different downy mildew control strategies
}

\author{
Ester Holcman ${ }^{1}$ (D) | Paulo Cesar Sentelhas ${ }^{1}$ | Marcel Bellato Spósito ${ }^{2}$ | \\ Marco Antônio Fonseca Conceição ${ }^{3}$ | Hilton Thadeu Zarate Couto ${ }^{4}$
}

\author{
${ }^{1}$ Department of Biosystems Engineering, \\ Agricultural College "Luiz de \\ Queiroz", University of São Paulo (ESALQ/ \\ USP), Piracicaba, SP, Brazil \\ ${ }^{2}$ Department of Crop Science, Agricultural \\ College "Luiz de Queiroz", University of São \\ Paulo (ESALQ/USP), Piracicaba, SP, Brazil \\ ${ }^{3}$ Brazilian Agricultural Research \\ Corporation/Tropical Viticulture \\ Experimental Station (Jales), Jales, SP, Brazil \\ ${ }^{4}$ Department of Forest Sciences, Agricultural \\ College "Luiz de Queiroz", University of São \\ Paulo (ESALQ/USP), Piracicaba, SP, Brazil

\section{Correspondence} \\ Ester Holcman, Agricultural College "Luiz de \\ Queiroz", University of São Paulo (ESALQ/ \\ USP), Piracicaba, SP, Brazil. \\ Email: esterholcman@yahoo.com.br \\ Funding information \\ National Council for Scientific and \\ Technological Development - CNPq, Grant/ \\ Award Number: 478200/2012-9; São Paulo \\ Research Foundation - FAPESP, Grant/ \\ Award Number: 2012/04615-7
}

\begin{abstract}
Viticulture has been expanding in tropical regions. However, the climate in these areas is generally favourable to the incidence of plant diseases, especially downy mildew. Plastic covers and warning systems have shown very positive results in disease control, but they are tools that have never been used simultaneously in a tropical area. The Vitis vinifera cv. BRS Morena table grape was evaluated as regards yield and quality under different downy mildew control strategies as carried out on vineyards trained on an overhead trellis system, covered by a black shading screen (BSS) or a braided polypropylene film (BPF), over a 3-year period. Different grapevine downy mildew management approaches defined the treatments: $\mathrm{Co}$ ) Control (no spraying); Ca) Conventional control (calendar); Ba) "Rule 3-10" (Atti Istituto Botanico, 8, 1947, 45); Ma25) Low-infection efficiency- $\mathrm{i}_{0}>25 \%$; and Ma75) High-infection efficiency $-\mathrm{i}_{0}>75 \%$ (Plant Disease, 84, 2000, 549). The occurrence of downy mildew and the amount of damage inflicted on vine yield and grape quality are directly related to the period of the crop cycle when there is rainfall. The use of the Ma75 warning system (Plant Disease, 84, 2000, 549) under braided polypropylene film resulted, for the most part, in similar vineyard productivity compared to $\mathrm{Ca}$, but did not influence the number of branches and its fertility. The other warning systems decreased productivity by $31.9 \%$ compared to $\mathrm{C}$. It was not possible to establish a relationship between the occurrence of downy mildew and its influence on grape sweetness and acidity. The use of warning systems led to a substantial reduction in fungicide sprays, approximately 66.7 to $71.3 \%$, compared to the calendar system commonly used by the vine growers, with the $B a$ (Atti Istituto Botanico, 8, 1947, 45) and Ma75 controls (Plant Disease, 84, 2000, 549) leading to the highest fungicide saving.
\end{abstract}

\section{KEYWORDS}

biometric variables, polypropylene plastic, table grape, warning systems

\section{1 | INTRODUCTION}

The planting of table grapes in tropical areas has been expanding due to bud dormancy breaking techniques and crop management adequacy depending on the region and climate in which the crop is to be cultivated (Pommer \& Barbosa, 2009). However, in the areas studied, climate has been a limiting factor, since it favours the development of diseases that can cause damage and loss in the vineyards, where the predominant disease is downy mildew, caused by Plasmopara viticola (Berk \& Curt. Berl. \& de Toni), (González-Rodríguez, Cancho-Grande, 
\& Simal-Gándara, 2011). Downy mildew is capable of causing up to $100 \%$ losses in production (Naves \& Sônego, 2006). This panorama requires intensive chemical control due to the destructive nature of the disease, increasing production cost and environmental and human contamination risks (Batista, Barbosa, Terao, Moura, \& Batista, 2008). Management strategies that change environmental conditions are an effective way to control this plant disease, by creating pathogen unfavourable conditions (Agrios, 2005). One of these strategies is protected cultivation, which has shown excellent results for fungal disease control, according to several studies carried out in Brazil (Batista et al., 2008; Chavarria et al., 2007; Genta et al., 2010; Pedro Júnior, Hernandes, \& Rolim, 2011). Plastic covering prevents applied fungicide removal by rainfall (Batista et al., 2008) and creates a partial physical barrier to ultraviolet light, reducing fungicide degradation (Genta et al., 2010). These two aspects increase fungicide residual period, making disease control more effective. Plastic covering is a viable alternative for reducing grape downy mildew severity and, therefore, the frequency of spray application, mainly in areas or periods with intense rainfall occurrence. In the northwestern region of the state of São Paulo, Brazil, it is very common to use black plastic screens over the vineyards for grape cultivation protection against hail and bird attack (Tecchio, Bettiol Neto, Barbosa, \& Tucci, 2011). These plastic screens, however, cannot be used for the purpose of disease control.

Plant disease warning systems have not been installed in tropical areas, despite the intense spraying programme carried out annually. These systems determine the best moment to apply control measures (Gleason et al., 2008), based on weather condition favourability for disease infection (Bardin, Pedro Júnior, \& Moraes, 2010). Such systems rationalize the chemical products use and reduce costs, environmental pollution and chemical contamination (Gillespie \& Sentelhas, 2008). Relative humidity, air temperature, precipitation and leaf wetness duration determine the possibility of infection and are the most used variables in downy mildew warning systems (Gleason et al., 2008; Lalancette, Ellis, \& Madden, 1988). Baldacci (1947) and Madden, Ellis, Lalancette, Hughes, and Wilson (2000) developed warning systems that, for efficiency and simplicity of use, have been distributed worldwide. The "Rule 3-10" (Baldacci, 1947), elaborated in northern Italy, estimates $P$. viticola primary infection risk based on simultaneous occurrence of air temperature of $10^{\circ} \mathrm{C}$ or higher, vine shoots of at least $10 \mathrm{~cm}$ in length and minimum $10 \mathrm{~mm}$ of rainfall for 24 to $48 \mathrm{hr}$. Madden et al. (2000) proposed a P. viticola warning system, originally developed for American grapes in the state of Ohio (United States) (Lalancette et al., 1988), which is based on air temperature and leaf wetness duration for "Infection Efficiency" estimation (representing the number of lesions produced by zoospore).

The use of warning systems and protected cultivation simultaneously could be a promising way of achieving more rational plant disease control in tropical areas and promoting an increase in grape yield and quality. Given this background, the objective of this study was to evaluate the effectiveness of plastic covering combined with disease warning systems on yield and crop quality of Vitis vinifera $\mathrm{cv}$. BRS Morena table grape in a tropical area in the northwestern region of the state of São Paulo, Brazil.

\section{MATERIALS AND METHODS}

The experiment was carried out at the Tropical Viticulture Experimental Station of Embrapa Grape and Wine in Jales, in the state of São Paulo, Brazil $\left(20^{\circ} 16^{\prime} 08^{\prime \prime} \mathrm{S}\right.$, 50 $32^{\prime} 45^{\prime \prime} \mathrm{W}$, and $478 \mathrm{~m}$ altitude). According to Köppen classification, the region climate is Aw, which means tropical humid with rainy summers and moderate droughts during winter (Alvares, Stape, Sentelhas, Gonçalves, \& Sparovek, 2013). The predominant soil is Haplic Lixisol (Loamic) (FAO, 2014). The experiments were carried out in three rows of $120 \mathrm{~m}$ of Vitis vinifera cv. BRS Morena seedless table grape under "IAC 766" (106-8 Mgt $\times$ V. caribaea) rootstock, north-south oriented, with $3.0 \mathrm{~m}$ between vines, $2.5 \mathrm{~m}$ between first and second rows and $5.0 \mathrm{~m}$ between second and third rows, totalling $900 \mathrm{~m}^{2}$ (Figure 1). The vines were conducted on an overhead trellis system from April to August (2012 to 2014), leaving six to eight buds per branch. However, the data from 2013 will not feature in this study, because there were no symptoms of downy mildew in vineyards in that year.

Half of the vineyard was covered with braided polypropylene plastic film (waterproofed with low-density polyethylene, antiultraviolet filter, with $200 \mu \mathrm{m}$ of thickness, $185 \mathrm{~g} / \mathrm{m}^{2}$ of specific weight and 70 to $80 \%$ of solar radiation transmissivity) installed over a metallic arc-shaped structure (BPF). The other half of the vineyard was covered with black screen (high-density polyethylene monofilament, anti-ultraviolet filter, with $5.3 \times 2.1 \mathrm{~mm}$ mesh, $150 \mathrm{~g} / \mathrm{m}^{2}$ of specific weight, 80 to $82 \%$ of solar radiation transmissivity) (BSS). Irrigation was supplied via microsprinklers (nominal flow rate of $50 \mathrm{~L} / \mathrm{hr}$ ), and frequency and duration was determined by the Irrivitis irrigation management system (Conceição, 2012). Micrometeorological conditions were measured by automatic sensors installed under BPF and BSS. Air temperature (Tair) and
BPF

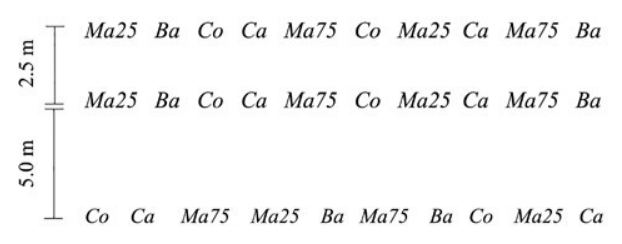

BSS

Ma25 Ba Co Ca Ma75 Co Ma25 Ca Ma75 Ba

Ma25 Ba Co Ca Ma75 Co Ma25 Ca Ma75 Ba

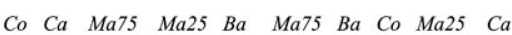

FIGURE 1 Schematic representation of the experimental field and distribution of the five treatments in the experimental area 
relative humidity $(\mathrm{RH})$ sensors were positioned between canopy and plastic covers, and incoming solar radiation (SR) sensors on an acrylic base above the canopies and wind speed sensors (WS) $0.80 \mathrm{~m}$ above the canopies and below the covers, connected to a datalogger (Campbell Scientific, CR23X). An automatic weather station (Campbell Scientific, CR510), at $100 \mathrm{~m}$ from the experimental area, provided rainfall data.

The experimental design was a randomized block with five treatments and six replications for each treatment in each covered environment (BPF and BSS). A whole vine was considered a replication. The treatments, under each type of covered environment, were defined by the following different grapevine downy mildew management programmes: $\mathrm{Co}$ ) Control-no spraying against downy mildew; $\mathrm{Ca}$ ) Conventional control (calendar)-which corresponds to one spraying per week during the dry periods and three sprayings per week during the rainy periods; $\mathrm{Ba}$ ) Warning system "Rule 3-10" (Baldacci, 1947)-based on the simultaneous occurrence of three conditions (Tair higher than or equal to $10^{\circ} \mathrm{C}$; branches with at least $10 \mathrm{~cm}$ of length, and occurrence of at least $10 \mathrm{~mm}$ of rainfall in $48 \mathrm{~h}$; Ma25) Warning system with low "Infection Efficiency" (i) (Madden et al., 2000)-based on Tair and LWD (leaf wetness duration), the fungicide spray being recommended when $\mathrm{i}_{0}>25 \%$; Ma75) Warning system with high-infection efficiency (Madden et al., 2000)-based on Tair and $L W D$, the fungicide spray being recommended when $\mathrm{i}_{0}>75 \%$.

The "Infection Efficiency" (i) was calculated from the following equation: $i=k^{*}\left(1+e^{-\rho}\right)^{1 /(1-m)}$ where: $k=-0.071+0.018^{*}$ Tair - $0.0005^{*}$ Tair $^{2} ; \quad \rho=-0.24 *$ LWD + 0.070*LWD*Tair - 0.0021* LWD*Tair $^{2}$; and $m=1.2$. According to the model, for any given period of time, $i$ can be predicted, as well as the percentages of $i$ relative to their maximum value, under favourable environmental conditions $\left(i_{0}\right)$, which is calculated by the ratio of current infection efficiency $(i)$ to maximum infection efficiency $\left(i_{\max }\right): i_{0}(\%)=\left(i / i_{\max }\right) * 100$ (Madden et al., 2000).

The fungicide used for Plasmopara viticola control was Ridomil Gold $M Z^{\circledR}$ (Mancozeb + Metalaxyl-M, Syngenta). The other fungicide used in the vineyard was Folicur (Tebuconazol), for powdery mildew control, and its application followed the scheme adopted by the regional growers. The spraying was done with a manual backpack sprayer of $20 \mathrm{~L}$, with nozzle cone type. The incidence (I) and severity (S) of downy mildew were evaluated weekly on all vine leaves of four branches on each of the six replications, from full flowering to early maturation, which totalled approximately 110 days. The I was obtained by counting the number of leaves that presented symptoms in relation to the total number of leaves per branch. The $\mathrm{S}$ was obtained by the percentage of leaf area with symptoms determined for each leaf of the evaluated branch. Subsequently, average values for all leaves of the branches evaluated were calculated so as to obtain average percentage of leaves with symptoms by branch $(I, \%)$ and mean leaf area percentage with disease symptoms per branch (S,\%). An eight level diagrammatic scale, described in Holcman (2014), was used for downy mildew severity assessment.

Plant phenological assessment, for both protected environments, was performed daily until harvesting, according to Lorenz et al. (1995). The branches and fertile bud counts were determined a month prior to harvest, in the six replications of each treatment, making a total of 30 vines evaluated for each environment. All bunches harvested from the 30 vines were counted and weighed. From the 30 vines, 10 berries of 3 bunches were selected, for stem and berry weight and width determination. Next, these berries were macerated to determine total soluble solids-TSS ( ${ }^{\circ}$ Brix) (manual refractometer-scale 0 to $32^{\circ} \mathrm{Brix}$ ), $\mathrm{pH}$ (digital pHmeter) and titratable acidity-TA (meq/L of fruit juice) (titration with $0.1 \mathrm{~N}$ sodium hydroxide solution and blue bromothymol indicator (RibéreauGayon, Peynaud, Ribéreau-Gayon, \& Sudraud, 1976). Comparisons between BPF and BSS (microclimate, disease, biometric and qualitative variables) were submitted to data variance analysis and the Kruskal-Wallis test at a level of $5 \%$ of probability using SAS statistical software package (ver. 9.3; SAS Institute, Cary, NC).

\section{3 | RESULTS}

The mean values of micrometeorological variables in covered vineyards (under BPF and BSS) and the rainfall data were obtained at the experimental station during 2012 and 2014, for each phenological stage (Table 1). For both years, the intensity of solar radiation (SR) inside BPF was lower than the SR obtained under BSS $(p<0.05)$. The decrease in SR below the BPF covering, from 2012 to 2014, can be explained by the ageing of the plastic cover and deposits of dust and soot particles over time. Although BSS had allowed higher SR transmissivity to the covered vineyard, causing higher temperature balance (short and long waves), the mean air temperature (Tair) and mean relative humidity $(\mathrm{RH})$ in this environment were similar to BPF (Table 1). This was a result of the increased air circulation promoted by the shading meshes of BSS, which favoured heat-sensitive exchange between the environments. The mean wind speed (WS) under BPF was lower when compared to BSS $(p<0.05)$. As for rainfall occurrence (rain), the frequency and intensity in 2012 were relatively high, mainly from April to June. This level of rainfall is not common in the region during this period and, consequently, this could be considered an atypical year (Table 1). In 2014, rain fell with lower intensity and frequency (Holcman, Sentelhas, Conceição, \& Couto, 2017)

The production variables, as well as the downy mildew I and $S$ were obtained for each year $(\mathrm{Y})$, environment $(\mathrm{E})$ and treatment $(T)$ evaluated (Table 2). Although there were significant differences in disease I and $\mathrm{S}(p<0.05)$ between the various sources evaluated, there was no effect of these factors on number of branches per vine. However, $E$ influenced the percentage of fertile branches. Under BPF, the branches were more fertile, with a higher number of buds sprouted. Despite this, the number of clusters was similar between covered environments. This occurred because in the cv. BRS Morena management, an average of two bunches per branch was usually preserved. This standardized the number of clusters per vine under the covered environments, ensuring a satisfactory cluster size. For the same reason, analysing 
TAB LE 1 Average values of incoming solar radiation (SR), air temperature (Tair), relative humidity (RH) and wind speed (WS) measured in each studied environment and in each experimental year in Jales, state of São Paulo, Brazil, being: braided polypropylene film (BPF) and black shading screen $18 \%$ (BSS)

\begin{tabular}{|c|c|c|c|c|c|c|c|c|c|c|}
\hline \multirow[b]{2}{*}{ Stage } & \multirow[b]{2}{*}{ DAP } & \multicolumn{2}{|c|}{$\mathrm{SR}\left(\mathrm{MJ} / \mathrm{m}^{2}\right.$ day) } & \multicolumn{2}{|c|}{ Tair $\left({ }^{\circ} \mathrm{C}\right)$} & \multicolumn{2}{|l|}{$\mathrm{RH}(\%)$} & \multicolumn{2}{|c|}{ WS (m/s) } & \multirow[b]{2}{*}{ Rain (mm } \\
\hline & & BPF & BSS & BPF & BSS & BPF & BSS & BPF & BSS & \\
\hline \multicolumn{11}{|l|}{2012} \\
\hline 0 & $5-16$ & $10.62 b$ & $11.72 \mathrm{a}$ & $21.1 \mathrm{a}$ & $21.1 \mathrm{a}$ & $81.0 \mathrm{a}$ & $77.5 \mathrm{a}$ & $0.36 \mathrm{~b}$ & $0.63 a$ & 42.7 \\
\hline 1 & $17-30$ & $7.86 \mathrm{~b}$ & $9.05 \mathrm{a}$ & $21.4 \mathrm{a}$ & $21.6 \mathrm{a}$ & $77.5 \mathrm{a}$ & $73.6 \mathrm{a}$ & $0.31 \mathrm{~b}$ & $0.62 \mathrm{a}$ & 38.0 \\
\hline 7 & $57-91$ & $9.94 \mathrm{~b}$ & $10.74 a$ & $19.8 \mathrm{a}$ & 19.9 a & $76.7 \mathrm{a}$ & 73.7 a & $0.30 \mathrm{~b}$ & $0.53 a$ & 2.5 \\
\hline 8 & $92-124$ & $12.20 \mathrm{~b}$ & $12.66 \mathrm{a}$ & $21.6 \mathrm{a}$ & $22.0 \mathrm{a}$ & $59.4 \mathrm{a}$ & $56.8 \mathrm{a}$ & $0.40 \mathrm{~b}$ & $0.58 \mathrm{a}$ & 0.0 \\
\hline \multicolumn{11}{|l|}{2014} \\
\hline 0 & $4-12$ & $9.83 \mathrm{~b}$ & $10.62 \mathrm{a}$ & $23.5 \mathrm{a}$ & $23.6 \mathrm{a}$ & $76.7 \mathrm{a}$ & $69.9 \mathrm{~b}$ & $0.29 \mathrm{~b}$ & $0.57 a$ & 7.9 \\
\hline 7 & $51-80$ & $8.58 \mathrm{~b}$ & $9.45 a$ & $21.0 \mathrm{a}$ & $21.1 \mathrm{a}$ & $72.0 \mathrm{a}$ & $65.5 \mathrm{~b}$ & $0.24 b$ & $0.61 \mathrm{a}$ & 0.0 \\
\hline 8 & $81-122$ & $8.63 \mathrm{~b}$ & $9.50 \mathrm{a}$ & $19.6 \mathrm{a}$ & $19.7 \mathrm{a}$ & $69.9 a$ & $63.7 \mathrm{~b}$ & $0.23 b$ & $0.53 a$ & 0.0 \\
\hline
\end{tabular}

Note. Phenological stages of vine development (Lorenz et al., 1995): 0 = budding; 1 = leaf development; 5 = inflorescence emergence; 6 = flowering; 7 = fruit development; 8 = fruit maturation. DAP = days after pruning. For each main factor separately, averages followed by different letters in the same line differ statistically from each other by Kruskal-Wallis test $(p<0.05)$.

TAB LE 2 Productivity variables and severity of downy mildew (\%) in BRS Morena vineyard comparing the factors year, environment and treatment separately: braided polypropylene film (BPF); black shading screen 18\% (BSS); Co = control; $\mathrm{C} a=\mathrm{calendar}$; $\mathrm{Ba}=\mathrm{Baldacci}(1947)$; Ma25 = Madden et al. (2000) $-\mathrm{i}_{0}$ de 25\%; Ma75 = Madden et al. (2000) $-\mathrm{i}_{0}$ de $75 \%$

\begin{tabular}{|c|c|c|c|c|c|c|c|c|}
\hline \multirow[b]{2}{*}{ Source } & \multirow{2}{*}{$\frac{\text { Number of branch }}{\text { plant }^{-1}}$} & \multirow{2}{*}{$\begin{array}{l}\begin{array}{l}\% \text { fertile } \\
\text { branches }\end{array} \\
\text { plant }^{-1}\end{array}$} & \multicolumn{2}{|c|}{ Number of clusters } & \multicolumn{2}{|c|}{ Yield (kg) } & \multirow{2}{*}{$\begin{array}{l}\text { Disease incidence } \\
\text { I (\%) }\end{array}$} & \multirow{2}{*}{$\begin{array}{l}\text { Disease severity } \\
\mathrm{S}(\%)\end{array}$} \\
\hline & & & plant $^{-1}$ & branch $^{-1}$ & plant $^{-1}$ & branch $^{-1}$ & & \\
\hline \multicolumn{9}{|l|}{ Year $(Y)$} \\
\hline 2012 & $37.1 \mathrm{a}$ & $89.1 \mathrm{a}$ & $45.5 b$ & $1.2 \mathrm{~b}$ & $7.12 \mathrm{a}$ & $0.18 \mathrm{a}$ & $56.00 \mathrm{a}$ & $4.48 \mathrm{a}$ \\
\hline 2014 & $41.3 \mathrm{a}$ & $85.5 \mathrm{a}$ & $61.6 \mathrm{a}$ & $1.6 \mathrm{a}$ & $6.49 a$ & $0.17 \mathrm{a}$ & $3.27 \mathrm{~b}$ & $0.10 \mathrm{~b}$ \\
\hline BPF & $39.1 \mathrm{a}$ & 88.9 a & $54.4 \mathrm{a}$ & $1.4 \mathrm{a}$ & $7.34 \mathrm{a}$ & $0.19 \mathrm{a}$ & $9.73 \mathrm{~b}$ & $0.29 \mathrm{~b}$ \\
\hline BSS & $39.3 \mathrm{a}$ & $85.7 \mathrm{~b}$ & $35.5 \mathrm{~b}$ & $1.0 \mathrm{~b}$ & $2.77 \mathrm{~b}$ & $0.08 b$ & $49.54 \mathrm{a}$ & $4.30 \mathrm{a}$ \\
\hline \multicolumn{9}{|c|}{ Treatment $(\mathrm{T})$} \\
\hline Co & $38.5 \mathrm{a}$ & $82.3 \mathrm{a}$ & $32.8 \mathrm{c}$ & $0.9 c$ & $2.58 c$ & $0.07 d$ & 47.17 a & $6.27 \mathrm{a}$ \\
\hline Ma75 & $41.8 \mathrm{a}$ & 88.9 a & $48.9 \mathrm{a}$ & $1.2 a b$ & $6.10 a b$ & $0.14 b$ & $25.71 b$ & $1.11 b$ \\
\hline
\end{tabular}

For each main factor separately, averages followed by different letters in the same column differ statistically from each other by Kruskal-Wallis test $(p<0.05)$.

$\mathrm{E}$ and $\mathrm{T}$, a relationship between the number of clusters and the disease parameters I and $\mathrm{S}$ was also not clear. However, it is possible to verify that the number of clusters tended to be lower in 2012, the year of higher disease occurrence, and in Co, a treatment with higher disease pressure. The disease intensity in the first year of evaluation compromised grape cluster development. Similarly, Co treatment, for failure to disease control, compromised the number of clusters per branch and, consequently, per vine. It presented similar averages to some treatments based on warning systems, mainly $\mathrm{Ba}$ and Ma25. 
The occurrence of downy mildew deeply affected the yield-related variables. However, although disease levels were very different in 2012 and 2014 (56.00 and 3.27\% for I; 4.48 and $0.10 \%$ for S), the mean yields were similar in these two years. This means that once the disease has settled in the vineyard, this is enough to greatly affect yield. Different plastic covers (E) also influenced the yield variables. Under BPF, the yield was higher compared to the vineyard under BSS. This was due to the higher disease control under BPF, as a result of the micrometeorological changes provided by this plastic cover, mainly due to its impermeability to rainwater.

Disease levels (I and S) were higher in Co, compared to other treatments $(T)(p<0.05)$, once they had no disease control. The $\mathrm{Ca}$ treatment with more intensive fungicide application resulted in lower I. However, $\mathrm{S}$ values were similar among $\mathrm{C} a$ and the treatments based on warning systems. It means that warning systems were as efficient in controlling downy mildew as the treatment based on vine grower's fungicide schedule used in the region of the experimental area. The $T$ did not influence the number of branches and bud fertility, but had an effect on the other biometric variables (Table 2). $\mathrm{Ba}$ and Ma25 presented similarity to $\mathrm{Co}$ as regards not only in the number of clusters per branch, but also in their similarity to Ma75. Ca presented similar averages to $\mathrm{Ma75}$, for the same variable, highlighting that both treatments provided the best performances. For yield, warning systems were similar to each other. Only Ma75 was similar to $\mathrm{Ca}$ (yield per branch). Co recorded lower averages due to the higher disease pressure, being 54.5 and $51.7 \%$ lower than the other treatments, per plant and per branch, respectively.

The downy mildew I and S differences over the years $(Y)(p<0.05)$ had no effect on stem weight and width, berries weight, diameter and width (Table 3 ). For cluster weight, the averages were higher in
2014, a year in which there was less occurrence of the disease. The E source influenced all the biometric variables in the table, except the diameter of berries. Vine cultivation under BPF promoted the production of heavier clusters, stem and berries, as well as longer stem and berries compared to BSS $(p<0.05)$. The higher occurrence of disease in the vines under BSS caused a decrease in the biometric variables. It was also observed that the higher yield under BPF came from the increase in cluster size and weight, and not from the number of clusters since this was the same in the vineyards under both BPF and under BSS (Table 2).

The Co resulted in lower cluster weight, due to the high disease pressure of this treatment $(\mathrm{T})$, which prevented satisfactory cluster development and caused the fall of some berries infested by the pathogen. For this and the other biometric variables in this Table, in general, the warning system Ma25 yielded higher or similar means compared to $\mathrm{Ca}$. Taking this result into account, it can be deduced that, of all the warning systems, Ma25 provided the best vineyard performance since it was predominantly similar to only $\mathrm{Ca}$.

The $Y$ source had an effect on total soluble solids (TSS) and fruit $\mathrm{pH}$, but the effect was zero for titratable acidity (TA) (Table 4). The higher occurrence of disease in 2012 promoted the highest TSS and lowest $\mathrm{pH}$ of the harvested fruits. The different disease levels of grapevine downy mildew appear to have no influence on fruit acidity (for the most part, tartaric acid) when comparing all the years evaluated. TSS and TA were higher and, consequently, $\mathrm{pH}$ was lower in fruits harvested under BPF. The downy mildew control and distinct disease intensity conditioned by the different treatments tested did not affect fruit $\mathrm{pH}$, but the more diseased plants ( $\mathrm{Co}$ ) presented higher levels of TSS and TA.

Figure 2 shows the number of fungicide sprays for downy mildew control for each treatment. In the 2012 season, the microclimatic

TA B LE 3 Cluster, stem and berries characteristics of cv. BRS Morena and severity of downy mildew (\%) comparing years, environments and treatments separately: braided polypropylene film (BPF); black shading screen 18\% (BSS); $\mathrm{Co}=$ control; $\mathrm{Ca}=\mathrm{calendar} ; \mathrm{Ba}=\mathrm{Baldacci}$ (1947); Ma25 = Madden et al. (2000) $-\mathrm{i}_{0}$ de 25\%; Ma75 = Madden et al. (2000) $-\mathrm{i}_{0}$ de 75\%

\begin{tabular}{|c|c|c|c|c|c|c|c|c|}
\hline \multirow[b]{2}{*}{ Source } & \multirow{2}{*}{$\begin{array}{l}\text { Cluster } \\
\text { Weight } \\
\text { (g) }\end{array}$} & \multicolumn{2}{|l|}{ Stem } & \multicolumn{3}{|c|}{10 berries } & \multirow{2}{*}{$\begin{array}{l}\text { Disease } \\
\text { Incidence } \\
\text { I (\%) }\end{array}$} & \multirow{2}{*}{$\begin{array}{l}\text { Disease } \\
\text { Severity } \\
\mathrm{S}(\%)\end{array}$} \\
\hline & & $\begin{array}{l}\text { Weight } \\
\text { (g) }\end{array}$ & $\frac{\text { Width }}{\text { (cm) }}$ & $\begin{array}{l}\text { Weight } \\
\text { (g) }\end{array}$ & $\begin{array}{l}\text { Diameter } \\
(\mathrm{cm})\end{array}$ & $\frac{\text { Width }}{(\mathrm{cm})}$ & & \\
\hline \multicolumn{9}{|l|}{ Year $(\mathrm{Y})$} \\
\hline 2012 & $153.51 b$ & $5.59 \mathrm{a}$ & $12.62 \mathrm{a}$ & $33.84 a$ & $15.41 \mathrm{a}$ & $19.30 \mathrm{a}$ & $56.00 \mathrm{a}$ & $4.48 \mathrm{a}$ \\
\hline BPF & $110.26 \mathrm{a}$ & $4.24 \mathrm{a}$ & $12.54 \mathrm{a}$ & $31.37 a$ & $15.72 \mathrm{a}$ & $20.47 a$ & $9.73 \mathrm{~b}$ & $0.29 \mathrm{~b}$ \\
\hline BSS & $70.16 \mathrm{~b}$ & $3.08 \mathrm{~b}$ & $11.16 \mathrm{~b}$ & $30.33 b$ & $15.70 \mathrm{a}$ & $19.83 b$ & $49.54 \mathrm{a}$ & $4.30 a$ \\
\hline \multicolumn{9}{|c|}{ Treatment $(T)$} \\
\hline Co & $103.26 \mathrm{~d}$ & $3.99 c$ & $12.19 \mathrm{~b}$ & $29.86 c$ & $15.43 c$ & $19.72 \mathrm{c}$ & 47.17 a & $6.27 a$ \\
\hline Ma75 & $116.11 \mathrm{c}$ & $4.51 b c$ & $12.94 a b$ & $32.06 \mathrm{~b}$ & $15.97 \mathrm{~b}$ & $20.49 a b$ & $25.71 b$ & $1.11 \mathrm{~b}$ \\
\hline
\end{tabular}

For each main factor separately, averages followed by different letters in the same column differ statistically from each other by Kruskal-Wallis test $(p<0.05)$. 


\begin{tabular}{|c|c|c|c|c|c|}
\hline \multirow[b]{2}{*}{ Source } & \multirow{2}{*}{$\begin{array}{l}\begin{array}{l}\text { Total soluble } \\
\text { solids (TSS) }\end{array} \\
{ }^{\circ} \text { Brix }\end{array}$} & \multirow[b]{2}{*}{$\mathrm{pH}$} & \multirow{2}{*}{$\begin{array}{l}\begin{array}{l}\text { Titratable } \\
\text { acidity (TA) }\end{array} \\
\text { meq L }^{-1}\end{array}$} & \multirow{2}{*}{$\begin{array}{l}\text { Disease incidence } \\
\text { I (\%) }\end{array}$} & \multirow{2}{*}{$\begin{array}{l}\text { Disease severit) } \\
\mathrm{S}(\%)\end{array}$} \\
\hline & & & & & \\
\hline \multicolumn{6}{|l|}{ Year $(\mathrm{Y})$} \\
\hline 2012 & $20.7 a$ & $3.5 \mathrm{~b}$ & $106.00 \mathrm{a}$ & $56.00 \mathrm{a}$ & $4.48 a$ \\
\hline 2014 & $18.7 \mathrm{~b}$ & $4.1 \mathrm{a}$ & $100.77 \mathrm{a}$ & $3.27 b$ & $0.10 \mathrm{~b}$ \\
\hline \multicolumn{6}{|c|}{ Environment (E) } \\
\hline BPF & $20.5 \mathrm{a}$ & $3.8 \mathrm{~b}$ & 116.17 a & $9.73 b$ & $0.29 b$ \\
\hline BSS & $19.1 \mathrm{~b}$ & $4.1 \mathrm{a}$ & $93.67 \mathrm{~b}$ & $49.54 \mathrm{a}$ & $4.30 \mathrm{a}$ \\
\hline \multicolumn{6}{|c|}{ Treatment $(\mathrm{T})$} \\
\hline Co & $20.3 a$ & $3.85 \mathrm{a}$ & $114.56 \mathrm{a}$ & 47.17 a & $6.27 \mathrm{a}$ \\
\hline $\mathrm{Ca}$ & $19.7 a b$ & $3.79 \mathrm{a}$ & $102.67 \mathrm{~b}$ & $21.82 \mathrm{c}$ & $0.19 \mathrm{~b}$ \\
\hline $\mathrm{Ba}$ & $18.8 \mathrm{c}$ & $3.83 a$ & $96.56 \mathrm{c}$ & $28.00 \mathrm{~b}$ & $2.05 \mathrm{~b}$ \\
\hline Ma25 & $19.0 \mathrm{c}$ & $3.90 \mathrm{a}$ & $98.67 \mathrm{bc}$ & $25.48 b$ & $1.85 \mathrm{~b}$ \\
\hline Ma75 & $19.5 \mathrm{bc}$ & $3.89 a$ & $100.22 b c$ & $25.71 b$ & $1.11 \mathrm{~b}$ \\
\hline
\end{tabular}

TAB LE 4 Qualitative variables and severity of downy mildew (\%) in BRS Morena vineyard comparing the factors year, environment and treatment separately: braided polypropylene film (BPF); black shading screen $18 \%$ (BSS); $\mathrm{Co}=$ control; $\mathrm{Ca}=$ calendar; $\mathrm{Ba}=$ Baldacci (1947); Ma25 = Madden et al. (2000)- $\mathrm{i}_{0}$ de 25\%; Ma75 = Madden et al. $-\mathrm{i}_{0}$ de $75 \%$

For each main factor separately, averages followed by different letters in the same column differ statistically from each other by Kruskal-Wallis test $(p<0.05)$.

conditions were more favourable for the occurrence of disease, mainly due to the increase in the intensity and frequency of rainfall, with the warning systems indicating a greater need for control than in 2014. The number of sprayings in all treatments was the same in both environments (BPF and BSS), which was caused by similar Tair and $\mathrm{RH}$ conditions. In the late afternoon and evening period, when the $\mathrm{RH}$ reached high values, warning systems ( $\mathrm{Ma} 25$ and Ma75) were used to fix vine spraying recommendations for both environments on similar days and schedules. In addition, $\mathrm{Ca}$ and $\mathrm{Ba}$ treatments were applied with the same frequency under both BPF and BSS.

In a more detailed statistical analysis, evaluating downy mildew $\mathrm{I}$ and $\mathrm{S}$ for each $\mathrm{T}, \mathrm{Y}$ and $\mathrm{E}$, it was observed that differences between T had occurred only in 2012 (Table 5). In 2014, the presence of symptoms was very small and there was no significant difference between treatments in the vineyards grown under either covered environment (BPF and BSS). In 2012, under BPF, Co treatment resulted in the highest disease level in the plants, whereas $\mathrm{Ca}$ promoted efficient disease control, similar to that attained by the studied warning systems (Ba, Ma25 and Ma75). Under BSS, Ca provided better disease control compared to the warning models. These treatments, in turn, presented I and S levels similar to control (Co).
These results are attributable to BSS meshes allowing partial depositing of raindrops on grape plants, resulting in partial fungicide removal from the leaves and bunches, which reduces the control efficacy. Furthermore, the raindrops on the leaves contributed to spore dispersion to other parts of the canopy. Associated with this fact, wind speed under BSS was higher than under BPF (Table 1), which contributed to the transporting of spores in the vineyard. The only exception was for $\mathrm{Ma75}$, which did not differ from $\mathrm{C} a$ in relation to average $S(p<0.01)$, and was the treatment with the best downy mildew control under BSS.

\section{DISCUSSION}

Variation in disease levels over the years $(\mathrm{Y})$ (Tables 2-5) occurred due to differences in the rainy season's frequency and period (Table 1). In 2012, rainfall occurred at the plant's phenological stages susceptible to disease (stages 0 and 1), promoting pathogen dissipation and resulting in an epidemic, reaching the lowest averages of the biometric variables and compromising yield (Tables 2,3 and 2,3). In 2014 , rainfall was less intense and less frequent, but occurred the

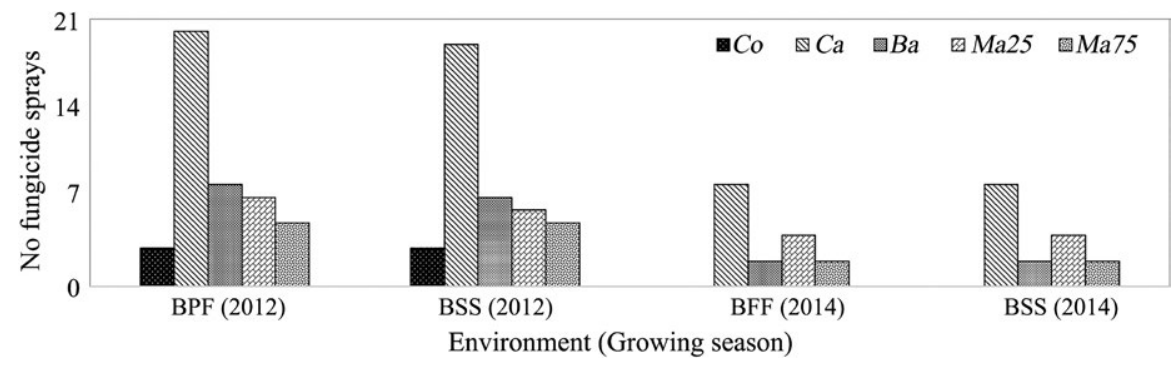

FIGURE 2 Number of fungicide sprays in the branches of cV BRS Morena relative to the five treatments performed over 2012 and 2014 crop seasons in Jales, state of São Paulo, Brazil. Braided polypropylene film (BPF); black shading screen 18\% (BSS); Co = control; $C a=$ calendar; $B a=$ Baldacci (1947); Ma25 = Madden et al. (2000) $-\mathrm{i}_{0}$ de 25\%; Ma75 = Madden et al. $-\mathrm{i}_{0}$ de $75 \%$ 
TAB LE 5 Downy mildew incidence and severity in BRS Morena vineyard for each treatment, year and environment, where BPF = braided polypropylene film; BSS = black shading screen 18\%; $\mathrm{Co}=$ control; $\mathrm{C} a=$ calendar; $\mathrm{B} a=$ Baldacci (1947); $\mathrm{Ma25}=\mathrm{Madden}$ et al. (2000) $-\mathrm{i}_{0}$ de 25\%; Ma75 = Madden et al. $-\mathrm{i}_{0}$ de $75 \%$

\begin{tabular}{|c|c|c|c|c|c|c|c|c|}
\hline Treatment & \multicolumn{2}{|c|}{ 2012-BPF } & \multicolumn{2}{|c|}{ 2012-BSS } & \multicolumn{2}{|c|}{ 2014-BPF } & \multicolumn{2}{|c|}{ 2014-BSS } \\
\hline Co & $86.48 a$ & $2.71 \mathrm{a}$ & $92.01 \mathrm{a}$ & $22.15 \mathrm{a}$ & $2.42 \mathrm{a}$ & $0.02 \mathrm{a}$ & $7.75 a$ & $0.21 a$ \\
\hline $\mathrm{Ca}$ & $0.35 b$ & $0.02 b$ & $83.67 \mathrm{~b}$ & $0.67 b$ & $0.46 a$ & $0.00 \mathrm{a}$ & $2.81 \mathrm{a}$ & $0.06 a$ \\
\hline $\mathrm{Ba}$ & $2.08 \mathrm{~b}$ & $0.09 \mathrm{~b}$ & $97.87 \mathrm{a}$ & $7.53 \mathrm{a}$ & $1.37 \mathrm{a}$ & $0.01 \mathrm{a}$ & $10.69 \mathrm{a}$ & $0.56 a$ \\
\hline
\end{tabular}

For each main factor separately, averages followed by different letters in the same column differ statistically from each other by Tukey's test ( $p<0.01$ ).

beginning of the crop cycle (stage 0). Rainfall at this time, even with low intensity, triggers the downy mildew infectious process. The disease levels (I and S) were lower compared to 2012. However, despite the mild pathogen attack, a number of biometric variables decreased and presented averages similar to 2012 . This probably happened due to plastic degradation and accumulation of dust over the years, reducing photosynthesis in the covered vines and also interfering in the productivity decrease and berry size (Tables 2,3 and 2,3). In addition, as mentioned above, the pathogen presence, regardless of its I and $\mathrm{S}$ levels, had already caused a decrease in grapevine production due to its high susceptibility to this disease.

The rainfall influenced the occurrence of downy mildew in vine under plastic coverings, even when they were partially permeable (BSS) or impermeable (BPF). Rain raises $\mathrm{RH}$ significantly, which is the main determinant of dew and leaf wetness. The presence of water on the leaves and fruit is the basic condition for the pathogen infection process (germination and penetration), resulting in epidemic occurrence (Cicogna, Dietrich, Gani, Giovanardi, \& Sandra, 2005). The optimum Tair for vine cultivation ranges from $20^{\circ} \mathrm{C}$ to $30^{\circ} \mathrm{C}$ (Reynier, 2005) and for downy mildew occurrence, from 5 to $30^{\circ} \mathrm{C}$ (Lalancette et al., 1988). The mean Tair observed between pruning and harvest ranged from 19.6 to $23.5^{\circ} \mathrm{C}$ under BPF and from 19.7 to $23.6^{\circ} \mathrm{C}$ under BSS (Table 1). These values are sufficient for full vine development, and also did not limit the downy mildew infectious process. Relative humidity $(\mathrm{RH})$ was slightly above the ideal for vines when the goal is to prevent certain fungal diseases. The mean values (pruning to harvest) ranged from $59.4 \%$ to $86.0 \%$ under BPF and 56.8 to $83.1 \%$ under BSS (Table 1). However, the ideal RH for vines is between $62.0 \%$ and $68.0 \%$, since values higher than $75 \%$, associated with high Tair, favour downy mildew and other diseases (Kishiro \& Caramori, 2007). High RH and saturation vapour pressure, on rainy days or not, was sufficient for downy mildew to find conditions satisfactory for its establishment under both plastic coverings.

Downy mildew I and S under BPF was much lower than that observed in BSS vines. Similarly, Batista et al. (2008 and Genta et al. (2010) verified that the use of impermeable plastic cover provided gains in this form of disease control even under favourable conditions. Du et al. (2015) also found that impermeable plastic cover reduced average severities of grape downy mildew by $81 \%$ on cv. Red Globe cultivar, since it avoided having raindrops on the vines. Czermainski and Sônego (2004) also observed the influence of rainfall on fungicide efficiency. Furthermore, the inclusion of chemical additives acted as ultraviolet solar radiation blockers (UV, $\lambda<400 \mathrm{~nm}$ ) in BPF composition. The fungicide degradation and, consequently, the reduction of its period of action are accelerated by UV radiation. The anti-UV pigmentation, used to increase plastic durability (Castellano, Candura, \& Scarascia, 2008), also caused a reduction in degradation rate of fungicide molecules (Chavarria et al., 2007), promoting a greater persistence of these molecules in vines. Consequently, yield of the vines cultivated under BPF was higher than under BSS, on average $165.0 \%$ per branch and $137.5 \%$ per plant (Table 2). Du et al. (2015) also found that vines under impermeable plastic increased vine yields by $110 \%-176 \%$, on average, when compared with vines cultivated in an open field.

As regards the treatments $(T)$, Ca required the highest frequency of sprayings during the two years for both covered environments (Figure 2). This treatment is the usual one performed by the growers in northwestern São Paulo, Brazil. As a result, this treatment promoted the lowest occurrence of downy mildew in both covered vineyards (Tables 2-5). However, conventional management of fungicides, according to the calendar, is not recommended in vineyards under plastic covers, since it can leave high levels of chemical residues on berries, resulting in a loss of quality, as reported by Pedro Júnior et al. (2011). The treatments based on warning systems ( $\mathrm{Ba}, \mathrm{Ma25}$, and Ma75), even with a lower spraying frequency (2 to 10 applications), controlled downy mildew as well as the calendar (Ca) schedule. The $\mathrm{Ba}$ treatment was the one that led to the highest spraying reductions, by $61.5 \%$ to $75 \%$ in relation to the calendar (Ca). Pedro Júnior, Pezzopane, and Martins (1999) and Fiorine (2006) also found similar results for open field vineyards in Brazil, but with spraying reductions ranging from $17 \%$ to $40 \%$.

All biometric parameters measured allowed for evaluating the effectiveness of each treatment $(T)$ on grape downy mildew control and on the gain in vineyard yield and quality. The different disease control treatments did not affect the number of branches and percentage of branches with fertile buds. Nonetheless, there was a significant impact of $T$ on the other variables, mainly in terms of number and weight of clusters and yield (Tables 2,3 and 
2,3). A number of clusters presented similar averages between treatments based on fungicide application calendar $(\mathrm{Ca})$ and the Ma75 warning system. Colombo et al. (2011) found similar results, verifying a similar number of clusters per vine among treatments with standard application of fungicides and with application reduced by 50 and $75 \%$, for V. vinifera cv. BRS Clara table grape. The unsprayed treatment ( $\mathrm{Co}$ ), which presented the highest levels of disease, promoted a reduction of $25.9 \%$ and $21.7 \%$ in number of clusters per branch and vine, respectively, and $24.3 \%$ in cluster weight compared to sprayed treatments ( $\mathrm{Ca}, \mathrm{Ba}, \mathrm{Ma} 25$ and Ma75). Co provided a 54.5 and $51.7 \%$ decrease in yield per branch and per vine, compared to other treatments. Comparing Ba, Ma25 and $\mathrm{Ma} 75$ to $\mathrm{Ca}$, we can see that the means were similar, except for Ma25, which was also similar to Co. Therefore, in general, the different warning systems had the same efficiency in disease control and also in comparison to $\mathrm{Ca}$.

Cv. BRS Morena biometric variables (Tables 2,3 and 2,3) were lower compared to the cultivar potential. This cultivar can produce around 20 to 25 tons per ha (Camargo, Nachtigal, Maia, Oliveira, \& Protas, 2003), corresponding to at least $15 \mathrm{~kg}$ per vine (considering a spacing of $2.5 \times 3.0 \mathrm{~m}$ ). However, the highest yield was approximately $7.02 \mathrm{~kg}$ per vine for the most productive treatment $(\mathrm{Ca})$, below its potential. The disease occurrence compromised cluster development, either in a more severe or milder manner depending on the treatment. It resulted in lower quantity and weight of clusters. However, it cannot be affirmed that only the presence of disease had caused this yield reduction. Certain treatments $(\mathrm{T})$ were able to control the incidence of disease reasonably, and even then, resulted in yields still below the cultivar's potential. In addition, even in years with low or no incidence of disease, the yield means were unsatisfactory. In 2012, this variable did not differ from 2014, although I and S were only 0.10 and $3.27 \%$ in 2014.

It is possible that floral abortion is one of the probable reasons why the vines have not been able to achieve their best performance, resulting in an unsatisfactory number of clusters per branch. According to Camargo et al. (2003), for cv. BRS Morena, 2 clusters per branch are usually produced. However, the cluster number per branch was always <2 (Table 2). For sprayed treatments, an average of 1.0-1.4 clusters per branch was obtained, less than the two clusters usually grown per branch for this cultivar. Pedro Júnior, Hernandes, Tecchio, and Pezzopane (2007) verified similar results; an average of 1.3 and 1.4 clusters per branch. Another important aspect to consider is that the cluster weight was, on average, between 100 and $165 \mathrm{~g}$, also lower than expected, that is, about 200 to $500 \mathrm{~g}$ (Brasil, 2002), even in the vines sprayed according to the calendar adopted by growers in the region (Ca) (163.31 g per cluster). Other authors, in the commercial cv. BRS Morena vineyards, obtained higher cluster weights, between 300 and $340 \mathrm{~g}$ (Mascarenhas, Silva, Lima, Mendonça, \& Holschunh, 2012; Santos et al., 2014). Flower abortions, reducing cluster numbers and mass, and in turn reducing vineyard productivity, can be facilitated by very vigorous rootstocks, as verified by Lira, Moares, Souza, Sales, and Leão (2017) in cv. BRS Clara vineyards. However, these authors observed that the cv. IAC
766 rootstock, the same used in the present study, did not present such effects.

Contrasting with what occurred in cluster performance, berry dimensions complied with the commercial requirements for both national and international markets. Cv. BRS Morena standard berry size is $16.0 \times 20.0 \mathrm{~mm}$ (EMBRAPA Uva e Vinho, 2005), wherein the minimum diameter required for local market commercial standards is $12.0 \mathrm{~mm}$ (Brasil, 2002) and between 14.0 and $17.0 \mathrm{~mm}$ for exports (Santos et al., 2014). In this study, individual berry size was on average $16.0 \times 20.3 \mathrm{~mm}$, corresponding to the commercial standards required and very similar to the values obtained by Lago-Vanzela, Da-Silva, Gomes, García-Romero, and Hermosín-Gutiérrez (2011) for the same cultivar.

Cv. BRS Morena presents a glucometric potential higher than $20^{\circ}$ Brix of total soluble solids (TSS), and its harvesting is recommended between 18 and $19^{\circ}$ Brix (Camargo et al., 2003). The average contents verified in the berries of the present work were 18.8 to $20.3^{\circ}$ Brix for all the experimental years (Table 4). Therefore, the TSS level was attained, for the most regularly recorded data, the recommended standards for this cultivar. Other authors, working with the same cultivar, obtained lower values, ranging from 14.9 to 17.0 ${ }^{\circ}$ Brix (Lago-Vanzela et al., 2011; Mattiuz, Miguel, Galati, \& Nachtigal, 2009; Santos, Silva, Oster, Mistura, \& Santos, 2013).

The $Y$ source influenced TSS levels (Table 4). In 2012, the TSS rose, with an average of $20.7^{\circ} \mathrm{Brix}$, but declined in 2014. This probably occurred due to the difference in rainfall levels over the years. Some authors identified low TSS values related to ripening and harvesting times during the rainy season (Pedro Júnior, Hernandes, Blain, \& Bardin-Camparotto, 2014), causing maturation delays (Schiedeck, Miele, Barradas, \& Mandelli, 1999). Otherwise, dry periods in the vine maturation final stage produced sweeter grapes (Kishino \& Caramori, 2007). However, there was no occurrence of rainfall during fruit maturation (Stage 8 ) in all the years evaluated (Table 1). Solar radiation (SR) and air temperature (Tair) are also related to fruit composition (Downey, Dokoozlian, \& Krstic, 2006). SR affects the levels and accumulation patterns of sugars (Reshef, Walbaum, Agam, \& Fait, 2017). This is because greater exposure to SR provides higher carbon availability and activates fruit metabolic processes, resulting in increases in TSS (Ollat, Gaudillere, \& Bravdo, 2000). Therefore, TSS variability may be related to SR reduction during stage 8 (maturation) from 2012 to 2014 (Table 1), discarding the hypothesis of Tair influence on this, since this variable was similar in all years and sources evaluated.

In addition, it was found that the E source had no effect on TSS, despite differences in SR transmittance within each environment due to physical characteristics of BPF and BSS (Table 1). As regards $\mathrm{T}, \mathrm{Co}$ had a severe disease attack and significant leaf area damage by disease symptoms, which compromised photosynthesis. However, this fact did not interfere in TSS, since average severities were similar for all treatments. Colombo et al. (2011) obtained similar results. These authors observed no differences between TSS of cV. BRS Clara berries under plastic cover comparing different levels of fungicide application for downy mildew control. 
The $\mathrm{Y}$ source had an effect on $\mathrm{pH}$ (Table 4). The $\mathrm{pH}$ values in 2014 were higher compared to 2012. Thus, the grapes of higher sweetness (high TSS), harvested in 2012, also presented the lowest $\mathrm{pH}$. Different from what occurred in the case of TSS, the distinct plastic coverings $(E)$ did influence grape $\mathrm{pH}$ $(p<0.05)$. Under BPF, $\mathrm{pH}$ was lower than that obtained in fruits grown under BSS. The $\mathrm{pH}$ of $\mathrm{cv}$. BRS Morena grapes cultivated based on different treatments $(T)$ reached similar averages, with a small variation. The results obtained in this study were similar to those reported by Manfroi, Mielle, Rizzon, Barradas, and Souza (2004) and Mascarenhas et al. (2012) and were higher than those obtained by Santos et al. (2013). The titratable acidity (TA) presented differences only in E and T. Under BPF, SR was lower and TA was higher when compared to BSS. These results agree with those from Sweetman, Sadras, Hancock, Soole, and Ford (2014). These authors observed that SR highly modulates malic acid levels, leading to decreases in fruit acidity. According to Reshef et al. (2017), SR affected organic acids levels in grape cluster. This is also consistent with the differences in $\mathrm{pH}$ obtained between the environments, because the variation in $\mathrm{pH}$ is inversely related to TA (Santos et al., 2014).

The increase in berry TA is related to organic acids and to increases in potassium cation (Manfroi et al., 2004). TA varied from 96 to $115.0 \mathrm{mEq} / \mathrm{L}$. For cv. BRS Morena, under plastic cover, a number of authors obtained TA values between 74.0 and 79.0 meq/L which were lower than those observed in the present study (Chavarria et al., 2008; Schiedeck et al., 1999). For Santos et al. (2014), the Brazilian seedless grapes presented TA ranging from $0.41 \%$ to $0.58 \%$. Converting TA from meq $\mathrm{L}^{-1}$ to $\%$, the mean values reached in the present trial were between $0.72 \%$ and $0.80 \%$, which were above the cultivar standard and higher than the mean values verified by other authors for the same cultivar (Mascarenhas et al., 2012; Mattiuz et al., 2009).

\section{5 | CONCLUSIONS}

The occurrence of downy mildew and its levels of incidence and severity affected both vine yield and grape quality, mainly when the rainy season coincided with the crop's most susceptible phenological stages, even under plastic coverings.

The use of warning systems under BPF and BSS promoted satisfactory disease control, resulting in similar efficiency between them and when compared to the conventional control (calendar), without consequences for vine yields. In addition, treatments based on warning systems resulted in a significant decrease in sprayings compared to conventional control usually practiced by vine growers in the northwestern region of the state of São Paulo, Brazil.

\section{ACKNOWLEDGEMENTS}

The authors are grateful to "EMBRAPA-Tropical Viticulture Experimental Station (EVT)" for providing vineyard areas and parts of the infrastructure, equipment and staff required for execution of the project; to "São Paulo Research Foundation-FAPESP" (no process 2012/04615-7) and "National Council for Scientific and Technological Development-CNPq" (no process 478200/2012-9) for supporting this project. The first author is grateful to "Coordination for the Improvement of Higher Education Personnel-CAPES" for a PhD scholarship.

\section{ORCID}

Ester Holcman (iD https://orcid.org/0000-0002-1406-3470

\section{REFERENCES}

Agrios, G. N. (2005). Plant disease caused by fungi. In G. N. Agrios (Ed.), Plant pathology, 5th ed. (pp. 383-614). Oxford, Oxfordshire, UK: Academic Press.

Alvares, C. A., Stape, J. L., Sentelhas, P. C., Gonçalves, J. L. M., \& Sparovek, G. (2013). Köppen's climate classification map for Brazil. Meteorologische Zeitschrift, 22(6), 711-728. https://doi. org/10.1127/0941-2948/2013/0507

Baldacci, E. (1947). Epifitie di Plasmopara viticola (1941-46) nell'Oltrepó Pavese ed adozione del calendario di incubazione come strumento di lotta. Atti Istituto Botanico, 8, 45-85.

Bardin, L., Pedro Júnior, M. J., \& Moraes, J. F. L. (2010). Climatic risk index of fungal diseases occurrence in 'Niagara Rosada' grapevine growing in the Polo Turístico do Circuito das Frutas, São Paulo State. Brazil. Bragantia, 69(4), 1019-1026.

Batista, F. S., Barbosa, M. A. G., Terao, D. E., Moura, M. S. B., \& Batista, D. C. (2008). Influence of plastic cover on downy mildew development in Festival grape cultivar. In: Embrapa Semi-Árido (Ed.), Jornada de Iniciação Científica da Embrapa Semi-árido (3 ed.) (pp. 51-56). Petrolina, Brazil: Embrapa Semi-Árido.

Brasil. (2002). Ministério da Agricultura, Pecuária e Abastecimento. Normative instruction n.1 of February 1, 2002. Technical regulation of identity and quality for fine table grapes classification. Official Gazette of Brazil Federative Republic. Brasília, DF, Feb 4th 2002, Section 1, p.2.

Camargo, U. A., Nachtigal, J. C., Maia, J. D. G., Oliveira, P. R. D., \& Protas, J. F. S. (2003). BRS Morena: nova cultivar de uva preta de mesa sem semente (new cultivar of seedless black table grape). Technical Communication 47. Retrieved from http://www. cnpuv. embrapa.br/publica/comunicado/cot047.pdf (verified Jan 30, 2018).

Castellano, S., Candura, A., \& Scarascia, M. G. (2008). Relationship between solidity ratio, colour and shading effects of agricultural nets. Acta Horticulturae, 801(1), 253-258.

Chavarria, G., Santos, H. P., Felippeto, J., Marodin, G. A. B., Bergamaschi, H., Cardoso, L. S., \& Fialho, F. B. (2008). Water relations and leaf gas exchange in vineyard with plastic overhead cover. Revista Brasileira De Fruticultura, 30, 1022-1029.

Chavarria, G., Santos, H. P., Sônego, O. R., Marodin, G. A. B., Bergamaschi, H., \& Cardoso, L. S. (2007). Incidence of diseases and needs of control in overhead covered grapes. Rev Bras Frutic, 29, 477-482.

Cicogna, A., Dietrich, S., Gani, M., Giovanardi, R., \& Sandra, M. (2005). Use of meteorological radar to estimate leaf wetness as data input for application of territorial epidemiological model (downy mildew - Plamopara viticola). Physics and Chemistry of the Earth, 30(1/3), 201-207.

Colombo, L. A., Assis, A. M., Sato, A. J., Tessmann, D. J., Genta, W., \& Roberto, S. R. (2011). Out of season production of 'BRS Clara' seedless grape under protected cultivation. Ciencia Rural, 41(2), 212-218. 
Conceição, M. A. F. (2012). Irrivitis: planilha para manejo da irrigação em videiras. Technical Communication 119. Retrieved from http://www. infoteca.cnptia.embrapa.br/infoteca/handle/doc/926523 (verified Mar 21, 2018).

Czermainski, A. B. C., \& Sônego, O. R. (2004). Effect of environmental conditions on efficacy of fungicides to downy mildew control in Vitis vinifera. Ciencia Rural, 34(1), 5-11.

dos Santos, A. E. O., Silva, E. O., Oster, A. H., de Lima, M. A. C., Mistura, C., \& Batista, P. F. (2014). Evolution of physiological maturity of seedless grapes grown in the Submiddle São Francisco Valley, Brazil. Revista Brasileira De Ciências Agrárias, 9(1), 25-30.

dos Santos, A. E. O., Silva, E. O., Oster, A. H., Mistura, C., \& dos Santos, M. O. (2013). Phenological behaviour and thermal requirements of seedless grapes grown in the Submiddle São Francisco River. Revista Brasileira De Ciências Agrárias, 8(3), 364-369.

Downey, M. O., Dokoozlian, N. K., \& Krstic, M. P. (2006). Cultural practice and environmental impacts on the flavonoid composition of grapes and wine: A review of recent research. American Journal of Enology and Viticulture, 57, 257-268.

Du, F., Deng, W., Yang, M., Wang, H., Mao, R., Shao, J., ... Zhu, S. (2015). Protecting grapevines from rainfall in rainy conditions reduces disease severity and enhances profitability. Crop Protection, 67, 261268. https://doi.org/10.1016/j.cropro.2014.10.024

Embrapa Uva e Vinho. (2005). Sistemas de Produção, 8. ISSN 1678876. Retrieved from http://www.cnpuv.embrapa.br/publica/sprod/ UvasSemSementes (verified Feb 14, 2018).

FAO - IUSS Working Group (2014). World reference base for soil resources 2014 international soil classification system for naming soils and creating legends for soil maps. Rome, Italy: FAO.

Fiorine, R. A. (2006). Sistemas agrometeorológicos de recomendação de época de pulverização para controle de doenças fúngicas da videira 'Niagara Rosada'. (Recommended agrometeorological systems in the powdering season for the control of the Niagara Rosada vine,) Campinas, BR, Instituto Agronômico de Campinas (IAC), Master's Dissertation.

Genta, W., Tessmann, D. J., Roberto, S. R., Vida, J. B., Colombo, L. A., Scapin, C. R., ... Clovis, L. R. (2010). Downy mildew management in protected cultivation of table grapes 'BRS Clara'. Pesquisa Agropecuaria Brasileira, 45(12), 1388-1395.

Gillespie, T. J., \& Sentelhas, P. C. (2008). Agrometeorology and plant disease management - A happy marriage. Science in Agriculture, 65(special issue), 71-75.

Gleason, M. L., Duttweiler, K. B., Batzer, J. C., Taylor, S. E., Sentelhas, P. C., Monteiro, J. E. B. A., \& Gillespie, T. J. (2008). Review: Obtaining weather data for input to crop disease-warning systems: Leaf wetness duration as a case study. Science in Agriculture, 65(special, issue):76-87. https://doi.org/10.1590/S0103-90162008000700013

González-Rodríguez, R. M., Cancho-Grande, B., \& Simal-Gándara, J. (2011). Decay of fungicide residues during vinification of white grapes harvested after the application of some new active substances against downy mildew. Food Chemistry, 125(2), 549-560. https://doi.org/10.1016/j.foodchem.2010.09.047

Holcman, E. (2014). Sistemas de alerta fitossanitário para o controle do míldio em vinhedos conduzidos sob coberturas plásticas no Noroeste Paulista (Phytosanitary warning systems for the control of mildew in vineyards under plastic roofs in the Northwest of São Paulo). Piracicaba, BR, College of Agriculture Luiz de Queiroz (University of São Paulo), PhD Thesis.

Holcman, E., Sentelhas, P. C., Conceição, M. A. F., \& Couto, H. T. Z. (2017). Vineyard microclimate and yield under different plastic covers. International Journal of Biometeorology, 62, 925-937. https://doi. org/10.1007/s00484-017-1494-y

Kishino, A. Y., \& Caramori, P. H. (2007). Fatores climáticos e o desenvolvimento da videira (Climatic factors And dvine development). In A. Y. Kishino, S. L. C. Carvalho, \& S. R. Roberto (Eds), Viticultura tropical: o sistema de produção no Paraná (pp. 59-86). (Tropical viniculture: the production system in Parana), Londrina, Brazil: IAPAR.

Lago-Vanzela, E. S., Da-Silva, R., Gomes, E., García-Romero, E., \& Hermosín-Gutiérrez, I. (2011). Phenolic composition of the Brazilian seedless table grape varieties BRS Clara and BRS Morena. Journal of Agriculture and Food Chemistry, 59(15), 8314-8323. https://doi. org/10.1021/jf201753k

Lalancette, N., Ellis, M. A., \& Madden, L. V. (1988). Development of an infection efficiency model of Plasmopara viticola on American grape based on temperature and duration of leaf wetness. Phytopathology, 78, 794-800.

Lira, M. M. C., Moares, D. S., Souza, E. R., Sales, W. D. S., \& Leão, P. D. S. (2017). Influência do porta-enxerto sobre a produção e características de uvas de mesa BRS Clara e Arizul no Submédio do Vale do São Francisco durante a safra do segundo semestre de 2016 (Influence of the rootstock on the production and characteristics of BRS Clara and Arizul Table grape in the Submedia of the San Francisco valley during the harvest in the second half of 2016). In: Embrapa Semiárido (ALICE) (Eds), Proc 12th Jornada de Iniciação Científica da Embrapa Semiárido, 2017 (pp. 341-346). Petrolina, Brazil.

Lorenz, D. H., Eichorn, K. W., Bleholder, H., Klose, R., Meier, U., \& Weber, E. (1995). Phenological growth stages of grapevine (Vitis vinifera L.) - Codes and descriptions according to the extended BBCH scale. Australian Journal of Grape and Wine Research, 1, 100-103.

Madden, L. V., Ellis, M. A., Lalancette, N., Hughes, G., \& Wilson, L. L. (2000). Evaluation of a disease warning system for downy mildew of grapes. Plant Disease, 84, 549-554. https://doi.org/10.1094/ PDIS.2000.84.5.549

Manfroi, L., Mielle, L. A., Rizzon, L. A., Barradas, C. I. N., \& Souza, P. V. D. (2004). Ripening evolution of Cabernet Franc grapes conducted in the lyre system. Ciência E Agrotecnologia, 28(2), 306-313.

Mascarenhas, R. J., Silva, S. M., de Lima, M. A. C., Mendonça, R. M. N., $\&$ Holschunh, H. J. (2012). Characterization of maturity and quality of Brazilian apirenic grapes in the São Francisco river Valley. Ciência E Tecnologia De Alimentos, 32(1), 26-33. https://doi.org/10.1590/ S0101-20612012005000010

Mattiuz, B., Miguel, A. C. A., Galati, V. C., \& Nachtigal, J. C. (2009). Effect of stored temperature in minimally processed seedless table grapes. Revista Brasileira De Fruticultura, 31(1), 44-52.

Naves, R. D. L., \& Sônego, O. (2006). Controle de doenças fúngicas em uvas de mesa na região noroeste do Estado de São Paulo (Control of fungal disease in the Northeastern region in the state of São Paulo). Bento Gonçalves, RS, Brazil: Embrapa Uva e Vinho.

Ollat, N., Gaudillere, J. P., \& Bravdo, B. A. (2000). Carbon balance in developing grapevine berries. Acta Horticulture, 526, 345-350. https:// doi.org/10.17660/ActaHortic.2000.526.37

Pedro Júnior, M. J., Hernandes, J. L., Blain, G. C., \& Bardin-Camparotto, L. (2014). Curva de maturação e estimativa do teor de sólidos solúveis e acidez total em função de graus-dia (Maturation curve and estimate of solubele solids and total acidity as a function of degree-days): Uva IAC 138-22 'Máximo'. Bragantia, 73(1), 81-85.

Pedro Júnior, M. J., Hernandes, J. L., \& Rolim, G. S. (2011). Y shaped trellis system for 'Niagara Rosada' grapevine grown with and without plastic overhead cover: Microclimate, yield, bunch quality and disease incidence. Bragantia, 70(1), 228-233.

Pedro Júnior, M. J., Hernandes, J. L., Tecchio, M. A., \& Pezzopane, J. R. M. (2007). Influence of training system on microclimate, yield and bunch quality of 'Niagara Rosada' grapevine, in Jundiaí-SP. Revista Brasileira De Fruticultura, 29(2), 313-317.

Pedro Júnior, M. J., Pezzopane, J. R. M., \& Martins, F. P. (1999). Use of rainfall to forecast time of spraying to control fungal diseases on 'Niagara Rosada' grape. Revista Brasileira De Agrometeorologia, 7, 107-111.

Pommer, C. V., \& Barbosa, W. (2009). The impact of breeding on fruit production in warm climates of Brazil. Revista Brasileira 
De Fruticultura, 31(2), 612-634. https://doi.org/10.1590/ S0100-29452009000200043

Reshef, N., Walbaum, N., Agam, N., \& Fait, A. (2017). Sunlight modulates fruit metabolic profile and shapes the spatial pattern of compound accumulation within the grape cluster. Frontiers in Plant Science. Retrieved from http://www.cnpuv.embrapa.br/publica/sprod/ UvasSemSementes (verified Mar 22, 2018).

Reynier, A. (2005). Manual de viticultura, 6th ed. Madrid, Spain: Mundi-Prensa.

Ribéreau-Gayon, J., Peynaud, É., Ribéreau-Gayon, P., \& Sudraud, P. (1976). Traité d'oenologie: Sciences et techniques de vin (Oenology treatise : Science and techniques of viniculture) ( $v$ 1). Paris, France: Dunod.

Schiedeck, G., Miele, A., Barradas, C. I. N., \& Mandelli, F. (1999). Maturation of Red Niagara grapes cultivated under plastic greenhouse and in the natural condition. Ciencia Rural, 29(4), 625-633.

Sweetman, C., Sadras, V. O., Hancock, R. D., Soole, K. L., \& Ford, C. M. (2014). Metabolic effects of elevated temperature on organic acid degradation in ripening Vitis vinifera fruit. Journal of
Experimental Botany, 65, 5975-5988. https://doi.org/10.1093/ jxb/eru343

Tecchio, M. A., Bettiol Neto, J. E., Barbosa, W., \& Tucci, M. L. S. (2011). Evolution and perspective of the temperate fruit crops in São Paulo state, Brazil. Revista Brasileira De Fruticultura, 33(special issue), 150157. https://doi.org/10.1590/S0100-29452011000500018

How to cite this article: Holcman E, Sentelhas PC, Spósito MB, Conceição MAF, Couto HTZ. Yield and quality of grapes cultivated under plastic coverings with different downy mildew control strategies. J Phytopathol. 2019;167:185-195. https:// doi.org/10.1111/jph.12786 